\title{
The Buffering Effects of Social Insurance for the Spread of Covid-19
}

\author{
Moein Mirani AhangarKolaei ${ }^{1}$, Eser Demir ${ }^{2}$, Tolga Constantinou 3 , Mostafa Toranji ${ }^{4}$, Tadashi Adino ${ }^{5}$, Nasrin \\ Tavassoli $^{6} \&$ Atefeh Noghani ${ }^{7}$ \\ ${ }^{1}$ Sharif University of Technology, Azadi Ave Tehran, Iran \\ ${ }^{283}$ Bogaziçi University, Department of Sociology, Bebek, Istanbul, Turkey \\ ${ }^{4}$ University of Tehran, Faculty of Economics, Kargar Shomali Ave, Tehran, Iran \\ ${ }^{5}$ University of Cyprus, Economic Research Center, University House, Nicosia, Cyprus \\ 6Isfahan University of Medical Sciences, Tadbir Building, International College, Hezar-Jerib Ave, Isfahan, Iran \\ ${ }^{7}$ Kashan University of Medical Sciences and Health Services, $15^{\text {th }}$ Khordad Square, Abazar Street, Kashan, Iran \\ moein.miraniahangarkolaei@gmail.com, eser.demir@boun.edu.tr, tolga.constantinou@boun.edu.tr, \\ mostafa.toranji@ut.ac.ir, tadashi.adino@ucy.ac.cy, tavassoli.nasrin@gmail.com, anoghani3@gmail.com
}

\begin{abstract}
Global pandemics are associated with substantial losses of human capital. The best strategy of policymakers in public health before a population-wide vaccination is to reduce the outbreak of the disease and finding ways to alleviate its negative consequences in society. Previous studies show that welfare programs have externalities in unintended areas and for unplanned outcomes including a wide range of health outcomes. In this paper, we show that payments under the Unemployment Insurance (UI) program have the potential to reduce the spread of the novel coronavirus. Applying a difference-in-difference technique on a monthly data of all US counties from January 2020 to January 2021, we document that the social insurance under the umbrella of UI payments can reduce the transmission rate of Covid-19. The results show heterogeneity across subsample with the largest effects among blacks, poor, and low educated regions.
\end{abstract}

Keywords: Health, Disease, Global Pandemic, Novel Coronavirus, Unemployment Insurance, Covid-19, Health, Unemployment Rate, Welfare Program, Social Insurance, Panel Data.

\section{Introduction}

The novel coronavirus started as a local pandemic in a small cluster in Wuhan China in January 2020 and spread across the globe in the following days at an unprecedented speed. As of January 2021, its global death toll adds up to 1.8 million counts with roughly 400,000 deaths only in the United States. The pandemic generated various responses from local and federal governments across the globe. These responses vary from encouragements of social distancing and personal health care to stay-at-home policies and welfare payments. One specific case of these welfare programs is the payments through Unemployment Insurance (UI) generosity program. The UI program has been the topic of many political debates as well as discussions among scholars in academia. Two reasons make the UI payments controversial. First, the UI payments create a large cost to the government and ultimately to taxpayers. Second, it also could generate disincentive among the unemployed people to stay out of the job market to benefit from the payments (Card et al., 2015; K. P. Classen, 1977; Farber \& Valletta, 2015; Krueger \& Mueller, 2010). This fact is most obvious when the recession is deep, many people lose their jobs, and the duration of unemployment is expected to be lengthy. The covid-19 pandemic generated this environment. Forbes (2020) reports that from March 2020 to August 2020 roughly 58 million laid-off workers filed for unemployment insurance. Assuming an average benefit of $\$ 10,886$, this number means that over six months (average duration of UI payments) the government has to pay $\$ 631$ billion in benefits. Comparing with the US GDP in 2019, the payments only between March-August has been roughly 3.3 percent of GDP.

These costs would easily be amplified if disincentives stop the unemployed to look for jobs. As Chetty (2006) suggested in his seminal work, an optimal design of UI schedule should be based on the program's costs and benefits to society. While the costs of the program are observable to both taxpayers and authorities the benefits go beyond their initial goals and cover a wide range of outcomes. A small but growing body of literature explores the potential positive externality of UI payments on various economic and non-economic outcomes. For instance, Beach \& Lopresti (2019) show the externality of UI payments for crime rates. The document that while the unemployment rate has positive effects on crime rates the higher UI benefits protect society against its impacts. In a similar study, NoghaniBehambari \& Maden (2020) document the buffering effect of unemployment insurance against crime rates. They use data on all US counties over the years 1990- 
2016 and apply a difference-in-difference model to show that while unemployment rates increase the incidence of crime at the county level the UI benefits could alleviate their negative effects. In another study, Noghanibehambari \& Salari (2020) show that the unemployment insurance program has the potential to improve birth outcomes. They found that pregnant mothers who are unemployed and reside in states with higher UI benefits compared to mothers residing in states with lower UI payments have higher birth weight.

Fewer low birth weight, and higher gestational period. They show that the UI payments encourage mothers to use better health insurance which in turn has positive effects on birth outcomes. The UI benefits also have been documented to affect drinking habits (Lantis \& Teahan, 2018), smoking (Fu \& Liu, 2019), foreclosure (Hsu et al., 2018), self-reported health (Ferrarini et al., 2014), general health (Kuka, 2020), mental health (Tefft, 2011), consumer credit (J. Hsu et al., 2014), suicide rates (T. J. Classen \& Dunn, 2012), reemployment success (Burgess \& Kingston, 1976), and education (Barr \& Turner, 2015; Kettunen, 1997). These effects are unplanned externalities for untargeted outcomes while the main targeted outcomes include income and consumption inequality. The degree to which the program was successful in smoothing the income and consumption of unemployed individuals has been documented in a relatively large literature (Baily, 1978; Baker \& Fradkin, 2017; Burdett et al., 2003; Chetty, 2006; T. J. Classen \& Dunn, 2012; Corneo \& Marquardt, 2000; East \& Kuka, 2015; Farber \& Valletta, 2015; Feldstein, 2005; Fredriksson \& Holmlund, 2001; Kettunen, 1997; Kroft \& Notowidigdo, 2016; Krueger \& Mueller, 2010; Landais et al., 2018; Long \& Polito, 2014; Mitman \& Rabinovich, 2015; Mueller et al., 2016; Noghanibehambari \& Rahnamamoghadam, 2020; Schmieder et al., 2012; Stiglitz \& Yun, 2005).

An avenue in economic research documents the effects of income and increases in earnings under welfare programs on health and mortality (Andrés, 2005; Kim, 2017; Tacke \& Waldmann, 2013). For instance, NoghaniBehambari, Noghani, et al. (2020) show that an increase in income during the first two years of life has potential health effects that appear at the end of life. Individuals who are born and spend the first two years of their life during an economic recession are more likely to die due to certain causes of death including cardiovascular diseases and malignant neoplasm diseases. They document that a 1 percent decrease in the aggregate business cycle in the year of birth is associated with a 2.2, 2.3, 3.1, 3.7, 0.9, and 2.1 percent increase in the likelihood of mortality in old ages due to malignant neoplasms, Diabetes Mellitus, cardiovascular diseases, Influenza, chronic respiratory diseases, and all other diseases, respectively. However, their result suggests that the onset of government welfare programs in the US was associated with alleviating this longterm link. They conclude that these early life effects could be offset with welfare payments specifically during difficult times. In a similar study, Gryzbowski et al. (2021) show the effects of UI payments on child mortality in the US between the years 1970-2000.

They apply a difference-in-difference technique and document that an increase of $\$ 1,000$ in UI payments reduces child mortality rates by about 48 percent from the mean. The income-mortality relationship could also hold for the long run. Several studies document that income shocks during the prenatal development and first years of life have the potential to influence adult morbidity and old-age mortality (Aalen, 1994; Adda et al., 2009; Arno et al., 2009, 2011; Cawley et al., 2009; Clark \& Royer, 2013; Cristia, 2009; Ensor et al., 2010; Espinosa \& Evans, 2008; Evans \& Moore, 2011; Lawlor et al., 2006; Lindahl, 2005; McCormick, 1985; Myrskylä, 2010a, 2010b; Myrskylä et al., 2013; Philipson \& Becker, 1998; Schnalzenberger, 2016; Snyder \& Evans, 2006; Strand \& Kunst, 2006). Unemployment Insurance benefits could act as a welfare program that although temporary but helps a vulnerable population, i.e. the unemployed individuals. The literature suggests that the UI payments could be beneficial for the health of people and specifically during a pandemic with ever-rising mortality rates. In this paper, we attempt to address this question. The main idea is whether those counties that are in more generous states reveal lower mortality rates compared to counties in less generous states. In so doing, we use data on all US counties (3140 counties) between January 2020 and January 2021 (thirteen months) and implement a difference-in-difference technique. The underlying assumption is that the variations in the predetermined UI schedule.

The main source of our identification strategy is probably orthogonal to other county characteristics that could also influence death rates and confirmed case rates. We find that a $\$ 1,000$ higher UI benefit is associated with roughly 0.028 fewer deaths per 100,000 population on a county-by-month basis which is about a 12.12 percent reduction from the mean. Also, an increase of $\$ 1,000$ in maximum benefit is associated 
with 3.84 fewer confirmed cases per 100,000 population on a county-by-month level, which is a reduction of 28.52 percent from the mean over the sample period. The results are robust across specifications and subsamples. The marginal effects are statistically significant and economically large. Poorer counties with a higher concentration of blacks, poor, and low educated individuals had experienced larger buffering effects of UI payments for the outbreak and death due to covid-19. The results of this paper have important policy implications for policymakers in public health and welfare designs. The optimal design of welfare programs, specifically the UI benefits, is based on its costs and benefits. In the absence of the potential external benefits, the designs will be only suboptimal. The results of this paper help the policymakers to reach the optimal design of UI benefits by documenting their positive externalities during a global pandemic. The rest of the paper is organized as follows. Section 2 discusses the data sources and empirical method. Section 3 reports the results. We depart some concluding remarks in section 4.

\section{Data Sources and Empirical Strategy}

The econometric strategy compares the mortality rates in counties with higher unemployment rates to counties with lower unemployment rates (first difference) in states with higher UI benefits to states with, lower UI benefits (second difference). Specifically, we implement the regressions of the following form:

$$
\begin{array}{r}
y_{c s t}=\beta_{1} \text { Unemployment Rate }_{c s t} \times \text { Maximum Benefit }_{s}+\beta_{2} \text { Unemployment Rate }_{c s t} \\
+\beta_{3} \text { Maximum Benefit }_{s}+\alpha_{1} T_{c s t}+\alpha_{2} X_{c s}+\zeta_{c}+\xi_{s t}+\zeta_{c} \times T+\varepsilon_{c s m}
\end{array}
$$

Where $y$ is the outcome (confirmed case or death due to covid-19 per 100,000 population). $c$ indexes county, $s$ state, and $t$ month-year. The data on cases and deaths are extracted from (USA-Facts, 2020). Unemployment rate is unemployment rate at the county level that varies by month and is taken from the Local Area Unemployment Statistics reports of the Bureau of Labor Statistics. The parameter Maximum benefit is a proxy for UI benefits.

It is calculated by multiplying the maximum weekly pay (the maximum an eligible laid-off worker could possibly get under the UI program). The maximum weekly payment (the maximum duration during which a UI eligible laid-off worker could be covered by state-level UI law). This value reflects the maximum possible amount of money that can be transferred to the laid-off eligible worker under the state-level UI law. This proxy has been widely implemented in the literature (Hsu et al., 2018; Noghanibehambari \& Salari, 2020). We also include average monthly temperature as it has been shown to affect the outbreak of covid-19. The parameter $T$ represents the average county-by-month temperature data extracted from NoghaniBehambari, Salari, et al. (2020). In $X$, we include a series of county and state economic indicators as follows. Population composition data is extracted from (SEER, 2019). Share of different industries in county employment is computed from the Quarterly Census of Employment and Wages data files. Job destruction data is extracted from the Quarterly Workforce Indicator.

Gross State Product (GSP) and personal income per capita are extracted from the Bureau of Economic Analysis. The parameters $\zeta$ and $\xi$ are counties and state-by-month fixed effects. In some specifications, we also include county by month-by--year linear trend, as represented by the interaction term $T \times \zeta$. All standard errors are clustered at the county level. The coefficient of interest is $\beta_{1}$ which shows the effect of a $\$ 1,000$ rise in UI benefits for a county that experiences a 1 percent rise in the unemployment rate. All regressions are weighted using the average county population over the sample period. 
Figure 1: Geographic Distribution of UI Benefits across the US States

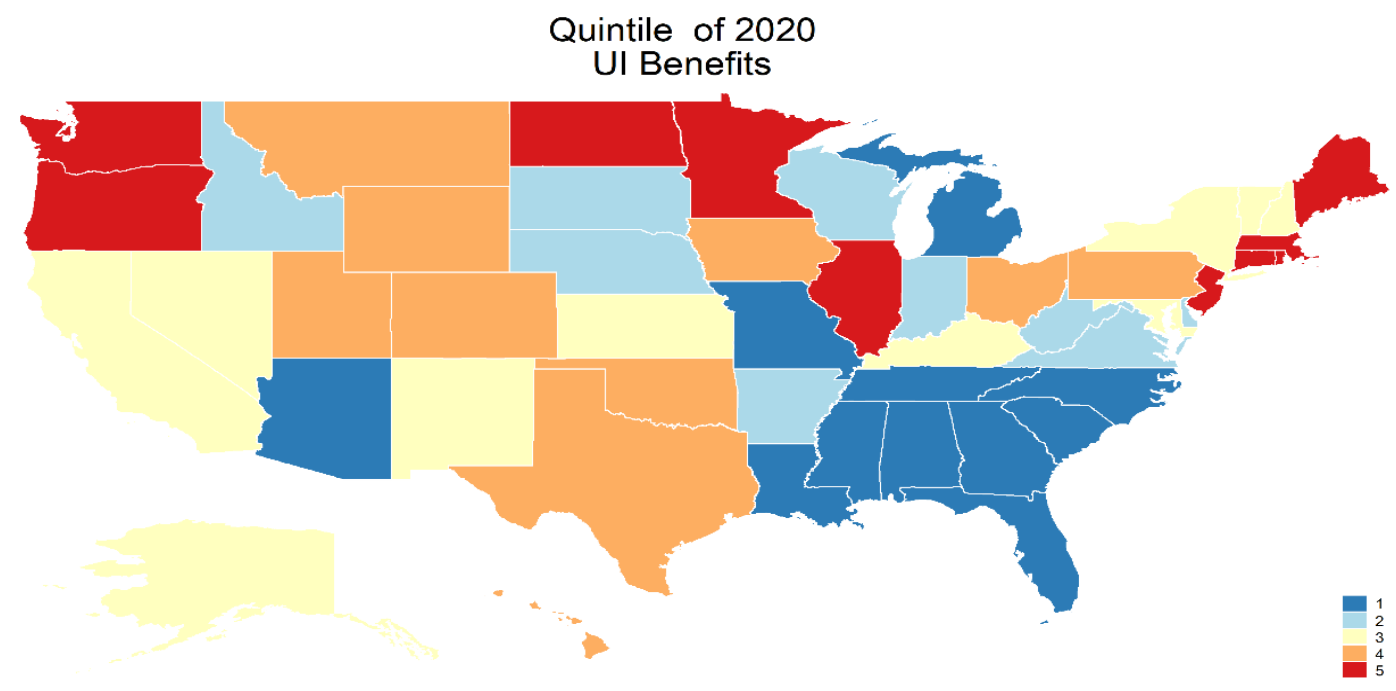

\section{Results}

Table 1 reports a summary statistics of the final sample. On average, the UI maximum benefit is $\$ 10,886$. The average death count at the county-by-month level is 0.231 counts per 100,000 population. Figure 1 shows the geographic distribution of UI maximum benefit across US states. Figure 2 shows the geographic distribution of confirmed cases and deaths based on quintiles of these variables in the top and bottom panels, respectively.

\section{Table 1: Summary Statistics}

\begin{tabular}{|c|c|c|c|c|c|}
\hline Variable & Observations & Mean & Std. Dev. & Min & Max \\
\hline Covid-19 Monthly Death Rate & 37,621 & 0.231 & 0.583 & 0 & 17.627 \\
\hline Covid-19 Total Death Rate & 37,621 & 115.037 & 87.261 & 0 & 834.598 \\
\hline $\begin{array}{l}\text { Covid-19 Monthly Confirmed } \\
\text { Cases Rate }\end{array}$ & 37,621 & 13.46 & 24.191 & 0 & 608.331 \\
\hline $\begin{array}{l}\text { Covid-19 Total Confirmed } \\
\text { Cases Rate }\end{array}$ & 37,621 & 6590.289 & 2811.116 & 0 & 27388.221 \\
\hline \multicolumn{6}{|l|}{$\begin{array}{l}\text { Average Characteristics at } \\
\text { 2019: }\end{array}$} \\
\hline \%Manufacturing Employment & 37,621 & 0.033 & 0.028 & 0 & 0.193 \\
\hline \%Mining Employment & 37,621 & 0.013 & 0.02 & 0 & 0.247 \\
\hline \%Construction Employment & 37,621 & 0.013 & 0.01 & 0 & 0.216 \\
\hline \%Blacks & 37,621 & 9.912 & 14.6 & 0 & 86.391 \\
\hline$\%$ Whites & 37,621 & 85.845 & 16.221 & 9.27 & 99.454 \\
\hline \%Males & 37,621 & 50.102 & 2.241 & 42.996 & 73.425 \\
\hline \%Aged 25-65 & 37,621 & 50.265 & 3.167 & 28.821 & 72.653 \\
\hline Average Weekly Wages & 37,621 & 768.784 & 174.289 & 436.67 & 2430.1 \\
\hline Ln Total Wages & 37,621 & 19.734 & 1.757 & 14.632 & 26.403 \\
\hline Per Capita Income & 37,621 & 41836.027 & 11508.849 & 11900.763 & 233150.06 \\
\hline Average Monthly Earnings & 37,621 & 3175.572 & 721.66 & 1658.667 & 9836.333 \\
\hline Job Destruction Rate & 37,621 & 0.043 & 0.016 & 0.008 & 0.241 \\
\hline \%Less than High School & 37,621 & 13.408 & 6.338 & 1.2 & 66.3 \\
\hline Population Density & 37,621 & 226.813 & 1269.112 & .035 & 48229.375 \\
\hline \multicolumn{6}{|l|}{ UI Schedule at 2020: } \\
\hline UI Maximum Weeks & 37,621 & 24.088 & 4.231 & 12 & 30 \\
\hline UI Maximum Weekly Pay & 37,621 & 442.715 & 125.741 & 235.294 & 1104.38 \\
\hline UI Maximum Benefit & 37,621 & 10886.89 & 4123.764 & 3304.129 & 33131.398 \\
\hline
\end{tabular}




\begin{tabular}{llllll}
\hline Log UI Maximum Benefit & 37,621 & 9.214 & 0.424 & 8.103 & 10.408 \\
Unemployment Rate & 37,621 & 7.063 & 3.971 & 0.4 & 41 \\
\hline
\end{tabular}

Figure 2: Geographic Distribution of Confirmed Cases and Deaths due to Covid-19 across the US States

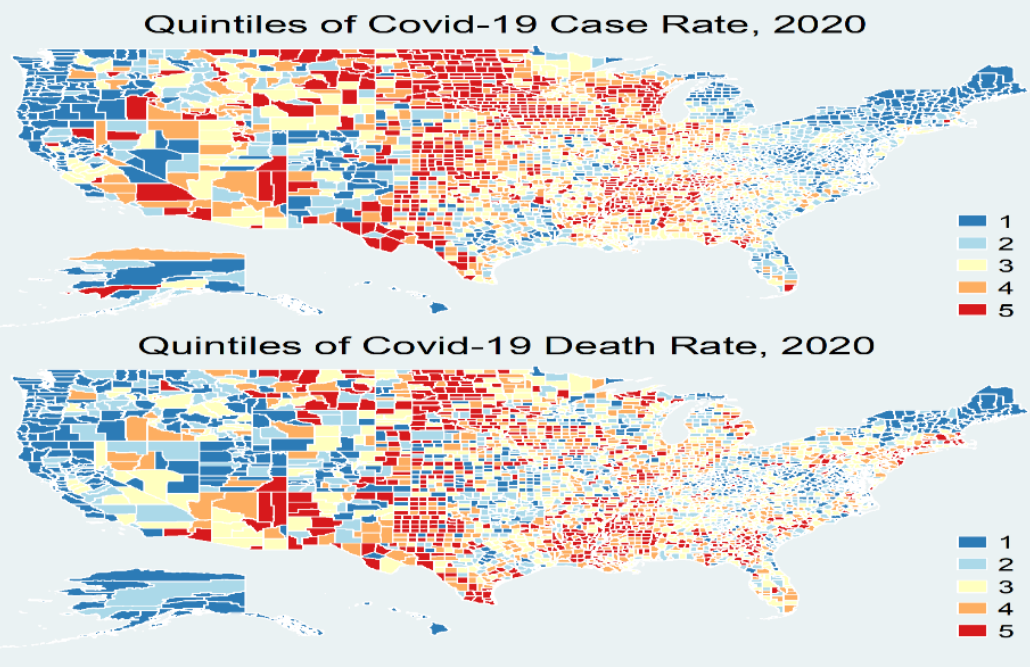

Table 2 reports the main results of the paper. An increase of $\$ 1,000$ in maximum UI benefit is associated with 0.022 fewer death rates (death per 100,000 individuals) in a county-by-month level. This effect is larger for counties with a higher unemployment rate. Looking at the difference in difference (hereafter DiD term), for a 1 percent higher unemployment rate, an increase of $\$ 1,000$ in maximum UI benefits is associated with 0.025 fewer death rate (column 1). This effect holds quite robust when we include county-by-month linear trend (column 2) and add state and county level indicators as a control ${ }^{1}$ (column 3 ). In the full specification, an increase of $\$ 1,000$ in maximum UI benefits is associated with 0.028 fewer death rates and 3.84 fewer inflicted persons at the county-by-month level. To put these numbers into perspective, an increase of $\$ 1,000$ in maximum UI benefits leads to a reduction of 12.12 and 28.52 percent from the mean of death rate and confirmed case rate, respectively.

Table 2: The Nexus between UI Maximum Benefit, Unemployment Rate, and the Outbreak of Covid-19

\begin{tabular}{|c|c|c|c|c|c|c|}
\hline & \multicolumn{3}{|c|}{ Covid-19 Death Rate } & \multicolumn{3}{|c|}{ Covid-19 Case Rate } \\
\hline & (1) & (2) & (3) & (4) & (5) & (6) \\
\hline UI Maximum Benefits & $\begin{array}{l}-0.022^{* *} \\
(0.009)\end{array}$ & $\begin{array}{l}-0.019^{* *} \\
(0.008)\end{array}$ & $\begin{array}{l}-0.016^{*} \\
(0.008)\end{array}$ & $\begin{array}{l}-1.115^{* * *} \\
(0.409)\end{array}$ & $\begin{array}{l}-0.975^{* *} \\
(0.468)\end{array}$ & $\begin{array}{l}-0.846^{*} \\
(0.388)\end{array}$ \\
\hline Unemployment Rate & $\begin{array}{l}1.125^{* *} \\
(0.514)\end{array}$ & $\begin{array}{l}1.008^{*} \\
(0.498)\end{array}$ & $\begin{array}{l}0.894^{*} \\
(0.476)\end{array}$ & $\begin{array}{l}39.282^{* * *} \\
(17.463)\end{array}$ & $\begin{array}{l}12.135 \\
(14.863)\end{array}$ & $\begin{array}{l}10.567 \\
(12.349)\end{array}$ \\
\hline $\begin{array}{l}\text { UI Maximum Benefits } \times \\
\text { Unemployment Rate }\end{array}$ & $\begin{array}{l}-0.019^{* * *} \\
(0.004)\end{array}$ & $\begin{array}{l}0.025^{* * *} \\
(0.004)\end{array}$ & $\begin{array}{l}0.028^{* * *} \\
(0.005)\end{array}$ & $\begin{array}{l}-2.569^{* * *} \\
(0.356)\end{array}$ & $\begin{array}{l}-3.489^{* * *} \\
(0.584)\end{array}$ & $\begin{array}{l}-3.846^{* * *} \\
(0.595)\end{array}$ \\
\hline County Fixed Effects & Yes & Yes & Yes & Yes & Yes & Yes \\
\hline Year Fixed Effects & Yes & Yes & Yes & Yes & Yes & Yes \\
\hline $\begin{array}{l}\text { State-by-Month Fixed } \\
\text { Effects }\end{array}$ & Yes & Yes & Yes & Yes & Yes & Yes \\
\hline $\begin{array}{l}\text { County-by-Month } \\
\text { Linear Trend }\end{array}$ & No & Yes & Yes & No & Yes & Yes \\
\hline
\end{tabular}

${ }^{1}$ Controls include: percentage manufacturing employment, percentage mining employment, percentage construction employment, percentage blacks, percentage whites, percentage foreign nationals, percentage males, percentage aged 25-65, and percentage less than high school, average weekly wages, Log total wages, job destruction rate, and per capita income. 


\begin{tabular}{lllllll}
\hline Controls & No & No & Yes & No & No & Yes \\
$\mathrm{R}^{2}$ & 0.133 & 0.162 & 0.184 & 0.348 & 0.413 & 0.440 \\
Observations & 37,621 & 37,621 & 37,621 & 37,621 & 37,621 & 37,621 \\
\hline
\end{tabular}

Notes: Standard errors are reported in parenthesis and clustered at the state level. All regressions are weighted by the average county population. County and state controls are explained in the text.

Next, we show the heterogeneity of the main results across subsamples in Table 3. Since the main focus is on the DiD term, we only report the results for the DiD coefficient ( $\alpha_{1}$ in equation 1$)$. For 1 percent higher county-level unemployment rate, an increase of $\$ 1,000$ maximum UI benefits is associated with $0.057,0.037$, and 0.067 fewer death rates for counties above-median blacks, above median low education, and belowmedian per capita personal income. The effects and the percentage changes from the mean are larger among the poor counties, counties with a higher concentration of blacks, and counties with more low educated individuals. The observed variation in the effects of welfare and income on confirmed cases and mortality is in-line with previous literature that document the racial and socioeconomic disparities in the outbreak of covid-19 (Allen et al., 2021; Choi \& Unwin, 2020; Figueroa et al., 2020; Kopel et al., 2020; Li et al., 2020; McClure et al., 2020; Paul et al., 2020; Yang et al., 2020).

Table 3: The Heterogeneity of the Main Results across Subsamples

\begin{tabular}{lllllll}
\hline & $\begin{array}{l}\text { Above } \\
\text { Median } \\
\text { Blacks }\end{array}$ & $\begin{array}{l}\text { Below } \\
\text { Median } \\
\text { Blacks }\end{array}$ & $\begin{array}{l}\text { Above } \\
\text { Median } \\
\text { Low } \\
\text { Education }\end{array}$ & $\begin{array}{l}\text { Below } \\
\text { Median } \\
\text { Low } \\
\text { Education }\end{array}$ & $\begin{array}{l}\text { Above } \\
\text { Median } \\
\text { Income }\end{array}$ & $\begin{array}{l}\text { Below } \\
\text { Median } \\
\text { Income }\end{array}$ \\
\hline $\begin{array}{l}(1) \\
\text { Panel A. Outcome: Covid-19 Death Rate }\end{array}$ & $(2)$ & $(4)$ & $(5)$ & $(6)$ \\
$\begin{array}{l}\text { UI Maximum Benefits } \\
\times \text { Unemployment Rate }\end{array}$ & $-0.057^{* * *}$ & $-0.029^{* *}$ & $-0.037^{* * *}$ & $-0.024^{* *}$ & -0.018 & - \\
& $(0.014)$ & $(0.009)$ & $(0.013)$ & $(0.012)$ & $(0.015)$ & $0.067^{* * *}$ \\
$(0.019)$
\end{tabular}

Panel B. Outcome: Covid-19 Case Rate

\begin{tabular}{|c|c|c|c|c|c|c|}
\hline $\begin{array}{l}\text { UI Maximum Benefits } \\
\times \text { Unemployment Rate }\end{array}$ & $\begin{array}{l}- \\
5.479^{* * *} \\
(1.149)\end{array}$ & $\begin{array}{l}-2.468 \\
* * * \\
(1.146)\end{array}$ & $\begin{array}{l}-3.854^{* * *} \\
(0.847)\end{array}$ & $\begin{array}{l}-2.729^{* * *} \\
(0.874)\end{array}$ & $\begin{array}{l}-2.256^{* *} \\
(1.059)\end{array}$ & $\begin{array}{l}- \\
7.089^{* * *} \\
(1.127)\end{array}$ \\
\hline County Fixed Effects & Yes & Yes & Yes & Yes & Yes & Yes \\
\hline Year Fixed Effects & Yes & Yes & Yes & Yes & Yes & Yes \\
\hline $\begin{array}{l}\text { State-by-Month Fixed } \\
\text { Effects }\end{array}$ & Yes & Yes & Yes & Yes & Yes & Yes \\
\hline $\begin{array}{l}\text { County-by-Month } \\
\text { Linear Trend }\end{array}$ & Yes & Yes & Yes & Yes & Yes & Yes \\
\hline State Controls & Yes & Yes & Yes & Yes & Yes & Yes \\
\hline Observations & 18,810 & 18,789 & 18,812 & 18,809 & 18,810 & 18,805 \\
\hline
\end{tabular}

Notes: Standard errors are reported in parenthesis and clustered at the state level. State controls are explained in the text. All regressions are weighted by the average county population. County and state controls are explained in the text.

\section{Conclusion}

The optimal design of a welfare program depends on its costs and benefits. For a social program like unemployment insurance, the costs to the taxpayers and government is mainly the payment burden on taxpayers and the potential moral conflicts associated with disincentives regarding job search. However, the benefits of the program are more controversial and could go beyond the initial targets and plans. Therefore, an optimal policy design requires quantifying the positive externalities of UI benefits on other outcomes. One potential area of UI externality is health. In this paper, we provided the potential externality of UI benefits on confirmed cases and death due to covid-19. We used county-by-month data from January 2020 to January 2021 across all US counties and implemented a difference-in-difference technique. We found that for a 1 
percent higher unemployment rate, a $\$ 1,000$ increase in maximum benefits is associated with 0.028 and 3.846 fewer death and confirmed cases per 100,000 population at the county-by-month level.

The results show heterogeneity across subsample with the largest effects among the disadvantaged population including blacks, poor, and low educated individuals. This heterogeneity shows that policies that aim to help the society during pandemics are more efficient if they focus on more vulnerable individuals including minorities, low educated people, and people below the poverty line. There are two primary policy suggestions based on the results of this paper. The first fact comes from the potential effect of income and welfare program on controlling the spread of a global disease. Policymakers who try to reduce the transmission rate of a population-wide disease should focus on policies that increase the welfare payments. Second, policymakers should differentiate between different subpopulations in welfare payments as the payments have differential effects among people from different socioeconomic and demographic groups.

\section{References}

Aalen, O. O. (1994). Effects of frailty in survival analysis. Statistical Methods in Medical Research, 3(3), 227243.

Adda, J., Banks, J. \& von Gaudecker, H. M. (2009). The Impact of Income Shocks on Health: Evidence from Cohort Data. Journal of the European Economic Association, 7(6), 1361-1399.

Allen, O., Brown, A. \& Wang, E. (2021). Socioeconomic Disparities in the Effects of Pollution on Spread of COVID-19: Evidence from US Counties. SSRN Electronic Journal.

Andrés, A. R. (2005). Income inequality, unemployment, and suicide: a panel data analysis of 15 European countries. Applied Economics, 37(4), 439-451.

Arno, P. S., House, J. S., Viola, D. \& Schechter, C. (2011). Social security and mortality: The role of income support policies and population health in the United States. Journal of Public Health Policy, 32(2), 234-250.

Arno, P. S., Sohler, N., Viola, D. \& Schechter, C. (2009). Bringing health and social policy together: The case of the earned income tax credit. Journal of Public Health Policy, 30(2), 198-207.

Baily, M. N. (1978). Some aspects of optimal unemployment insurance. Journal of Public Economics, 10(3), 379-402.

Baker, S. R. \& Fradkin, A. (2017). The impact of unemployment insurance on job search: Evidence from Google search data. Review of Economics and Statistics, 99(5), 756-768.

Barr, A. \& Turner, S. (2015). Out of work and into school: Labor market policies and college enrollment during the Great Recession. Journal of Public Economics, 124, 63-73.

Beach, B. \& Lopresti, J. (2019). LOSING BY LESS? IMPORT COMPETITION, UNEMPLOYMENT INSURANCE GENEROSITY, AND CRIME. Economic Inquiry, 57(2), 1163-1181.

Burdett, K., Lagos, R. \& Wright, R. (2003). Crime, inequality, and unemployment. American Economic Review, 93(5), 1764-1777.

Burgess, P. L. \& Kingston, J. L. (1976). The Impact of Unemployment Insurance Benefits on Reemployment Success. ILR Review, 30(1), 25-31.

Card, D., Johnston, A., Leung, P., Mas, A. \& Pei, Z. (2015). The effect of unemployment benefits on the duration of unemployment insurance receipt: New evidence from a regression kink design in Missouri, 20032013. American Economic Review, 105(5), 126-130.

Cawley, J., Moran, J. \& Simon, K. (2009). The impact of income on the weight of elderly Americans. Health Economics, 19(8), 979-993.

Chetty, R. (2006). A general formula for the optimal level of social insurance. Journal of Public Economics, 90(10-11), 1879-1901.

Choi, Y. \& Unwin, J. (2020). Racial Impact on Infections and Deaths due to COVID-19 in New York City. ArXiv.

Clark, D. \& Royer, H. (2013). The effect of education on adult mortality and health: Evidence from Britain. American Economic Review, 103(6), 2087-2120.

Classen, K. P. (1977). The Effect of Unemployment Insurance on the Duration of Unemployment and Subsequent Earnings. Industrial and Labor Relations Review, 30(4), 438.

Classen, T. J. \& Dunn, R. A. (2012). The effect of job loss and unemployment duration on suicide risk in the United States: a new look using mass-layoffs and unemployment duration. Health Economics, 21(3), 338-350. 
Corneo, G. \& Marquardt, M. (2000). Public pensions, unemployment insurance, and growth. Journal of Public Economics, 75(2), 293-311.

Cristia, J. P. (2009). Rising mortality and life expectancy differentials by lifetime earnings in the United States. Journal of Health Economics, 28(5), 984-995.

East, C. N. \& Kuka, E. (2015). Reexamining the consumption smoothing benefits of Unemployment Insurance. Journal of Public Economics, 132, 32-50.

Ensor, T., Cooper, S., Davidson, L., Fitzmaurice, A. \& Graham, W. J. (2010). The impact of economic recession on maternal and infant mortality: Lessons from history. BMC Public Health, 10(1), 1-9.

Espinosa, J. \& Evans, W. N. (2008). Heightened mortality after the death of a spouse: Marriage protection or marriage selection? Journal of Health Economics, 27(5), 1326-1342.

Evans, W. N. \& Moore, T. J. (2011). The short-term mortality consequences of income receipt. Journal of Public Economics, 95(11-12), 1410-1424.

Farber, H. S. \& Valletta, R. G. (2015). Do extended unemployment benefits lengthen unemployment spells? Evidence from recent cycles in the U.S. Labor market. Journal of Human Resources, 50(4), 873-909.

Feldstein, M. (2005). Rethinking social insurance. In American Economic Review, 95(1), 1-24.

Ferrarini, T., Nelson, K. \& Sjöberg, 0. (2014). Unemployment insurance and deteriorating self-rated health in 23 European countries. Journal of Epidemiology and Community Health, 68(7), 657-662.

Figueroa, J. F., Wadhera, R. K., Lee, D., Yeh, R. W. \& Sommers, B. D. (2020). Community-Level Factors Associated With Racial And Ethnic Disparities In COVID-19 Rates In Massachusetts. Health Affairs, 39(11), 1984-1992.

Forbes. (2020). Jobless Claims: 57.4 Million Americans Have Sought Unemployment Benefits Since MidMarch-Over 1 Million People Filed Last Week.

Fredriksson, P. \& Holmlund, B. (2001). Optimal Unemployment Insurance in Search Equilibrium. Journal of Labor Economics, 19(2), 370-399.

Fu, W. \& Liu, F. (2019). Unemployment insurance and cigarette smoking. Journal of Health Economics, 63, 3451.

Gryzbowski, W., Adamicz, A. \& Wysocki, H. (2021). The Health Externalities of Social Insurance: Evidence from Unemployment Insurance Benefits and Children Mortality.

Hsu, J., Matsa, D. \& Melzer, B. (2014). Positive Externalities of Social Insurance: Unemployment Insurance and Consumer Credit.

Hsu, J. W., Matsa, D. A. \& Melzer, B. T. (2018). Unemployment insurance as a housing market stabilizer. American Economic Review, 108(1), 49-81.

Kettunen, J. (1997). Education and unemployment duration. Economics of Education Review, 16(2), 163-170.

Kim, K. (2017). The relationships between income inequality, welfare regimes and aggregate health: a systematic review. European Journal of Public Health, 27(3), 397-404.

Kopel, J., Perisetti, A., Roghani, A., Aziz, M., Gajendran, M. \& Goyal, H. (2020). Racial and Gender-Based Differences in COVID-19. Frontiers in Public Health, 8, 418.

Kroft, K. \& Notowidigdo, M. J. (2016). Should Unemployment Insurance Vary with the Unemployment Rate? Theory and Evidence. The Review of Economic Studies, 83(3), 1092-1124.

Krueger, A. B. \& Mueller, A. (2010). Job search and unemployment insurance: New evidence from time use data. Journal of Public Economics, 94(3-4), 298-307.

Kuka, E. (2020). Quantifying the benefits of social insurance: Unemployment insurance and health. Review of Economics and Statistics, 102(3), 490-505.

Landais, C., Michaillat, P. \& Saez, E. (2018). A macroeconomic approach to optimal unemployment insurance: Theory. American Economic Journal: Economic Policy, 10(2), 152-181.

Lantis, R. \& Teahan, B. (2018). The effect of unemployment insurance on alcohol use and abuse following job loss. Economics and Human Biology, 30, 92-103.

Lawlor, D. A., Sterne, J. A. C., Tynelius, P., Davey Smith, G. \& Rasmussen, F. (2006). Association of childhood socioeconomic position with cause-specific mortality in a prospective record linkage study of 1,839,384 individuals. American Journal of Epidemiology, 164(9), 907-915.

Li, Q., Guan, X., Wu, P., Wang, X., Zhou, L., Tong, Y., Ren, R., Leung, K. S. M., Lau, E. H. Y., Wong, J. Y., Xing, X., Xiang, N., Wu, Y., Li, C., Chen, Q., Li, D., Liu, T., Zhao, J., Liu, M. \& Feng, Z. (2020). Early transmission dynamics in Wuhan, China, of novel coronavirus-infected pneumonia. In New England Journal of Medicine, 382(13), 1199-1207.

Lindahl, M. (2005). Estimating the effect of income on health and mortality using lottery prizes as an 
exogenous source of variation in income. Journal of Human Resources, 40(1), 144-168.

Long, I. W. \& Polito, V. (2014). Unemployment, Crime and Social Insurance. Cardiff Economics Working Papers.

McClure, E. S., Vasudevan, P., Bailey, Z., Patel, S. \& Robinson, W. R. (2020). Racial Capitalism Within Public Health-How Occupational Settings Drive COVID-19 Disparities. American Journal of Epidemiology, 189(11), 1244-1253.

McCormick, M. C. (1985). The Contribution of Low Birth Weight to Infant Mortality and Childhood Morbidity. New England Journal of Medicine, 312(2), 82-90.

Mitman, K. \& Rabinovich, S. (2015). Optimal unemployment insurance in an equilibrium business-cycle model. Journal of Monetary Economics, 71, 99-118.

Mueller, A. I., Rothstein, J. \& Von Wachter, T. M. (2016). Unemployment insurance and disability insurance in the Great Recession. Journal of Labor Economics, 34(S1), S445-S475.

Myrskylä, M. (2010a). The relative effects of shocks in early-and later-life conditions on mortality. Population and Development Review, 36(4), 803-829.

Myrskylä, M. (2010b). The effects of shocks in early life mortality on later life expectancy and mortality compression: A cohort analysis. Demographic Research, 22, 289-320.

Myrskylä, M., Mehta, N. K. \& Chang, V. W. (2013). Early-life exposure to the 1918 influenza pandemic and oldage mortality by cause of death. American Journal of Public Health, 103(7), e83--e90.

NoghaniBehambari, H. \& Maden, B. (2020). Unemployment insurance generosity and crime. Applied Economics Letters.

NoghaniBehambari, H., Noghani, F. \& Tavassoli, N. (2020). Early Life Income Shocks and Old-Age CauseSpecific Mortality. Economic Analysis, 53(2), 1-19.

Noghanibehambari, H. \& Rahnamamoghadam, M. (2020). Is income inequality reflected in consumption inequality in Iran? Middle East Development Journal, 1-20.

Noghanibehambari, H. \& Salari, M. (2020). Health benefits of social insurance. Health Economics.

NoghaniBehambari, H., Salari, M., Noghani, F. \& Tavassoli, N. (2020). The Effect of Temperature on COVID-19 Confirmed Cases: Evidence from US Counties. SSRN Electronic Journal.

Paul, A., Englert, P. \& Varga, M. (2020). Socio-Economic Disparities and COVID-19 in the USA. SSRN Electronic Journal.

Philipson, T. J. \& Becker, G. S. (1998). Old-Age Longevity and Mortality-Contingent Claims. Journal of Political Economy, 106(3), 551-573.

Schmieder, J. F., von Wachter, T. \& Bender, S. (2012). The Effects of Extended Unemployment Insurance Over the Business Cycle: Evidence from Regression Discontinuity Estimates Over 20 Years. The Quarterly Journal of Economics, 127(2), 701-752.

Schnalzenberger, M. (2016). Causal effect of income on health: Investigating two closely related policy reforms in Austria. Journal of the Economics of Ageing, 7, 6-16.

SEER. (2019). Surveillance, Epidemiology, and End Results (SEER) Program (www.seer.cancer.gov) Research Data (1975-2016). National Cancer Institute, DCCPS, Surveillance Research Program.

Snyder, S. E. \& Evans, W. N. (2006). The effect of income on mortality: Evidence from the social security Notch. Review of Economics and Statistics, 88(3), 482-495.

Stiglitz, J. E. \& Yun, J. (2005). Integration of unemployment insurance with retirement insurance. Journal of Public Economics, 89(11-12), 2037-2067.

Strand, B. H. \& Kunst, A. (2006). Childhood socioeconomic position and cause-specific mortality in early adulthood. American Journal of Epidemiology, 165(1), 85-93.

Tacke, T. \& Waldmann, R. J. (2013). Infant mortality, relative income and public policy. Applied Economics, $45(22), 3240-3254$.

Tefft, N. (2011). Insights on unemployment, unemployment insurance, and mental health. Journal of Health Economics, 30(2), 258-264.

USA-Facts. (2020). US Coronavirus Cases and Deaths | USAFacts.

Yang, T. C., Emily Choi, S. \& Sun, F. (2020). COVID-19 cases in US counties: roles of racial/ethnic density and residential segregation. Ethnicity \& Health, 1-11. 